\title{
Jaw musculature of Cyclarhis gujanensis (Aves: Vireonidae)
}

\author{
Previatto, DM. ${ }^{a}$ and Posso, SR. ${ }^{a *}$ \\ ${ }^{a}$ Laboratório de Ecologia Sistemática e Conservação de Aves Neotropicais - CPTL, \\ Universidade Federal de Mato Grosso do Sul - UFMS, Avenida Ranulpho Marques Leal, 3484, \\ CP 210, CEP 79620-080, Três lagoas, MS, Brazil \\ *e-mail: srposso@hotmail.com
}

Received: November 7, 2013 - Accepted: April 10, 2014 - Distributed: August 31, 2015

(With 3 figures)

\begin{abstract}
Cyclarhis gujanensis is a little bird which feeds on high number of large preys, such frogs, lizards, snakes, bats and birds. As there are few studies on the cranial anatomy of this species, we aimed to describe the cranial myology to contribute to the anatomical knowledge of this species and to make some assumptions about functional anatomy. Thus, we described the muscles from the jaw apparatus (external and internal adductor muscles, the muscles of the pterygoid system and the depressor muscles of the mandible). The adductor system is the greatest and multipinulated, particularly in its origin in the caudal portion of the temporal fossa. The depressor jaw muscles systems are enlarged with many components in complexity. The most of jaw apparatus muscles are short, but the strength (biting or crushing forces) from short feeding apparatus fibers probably is increased by high number of components and pinnulation. These anatomical aspects of the muscles indicate a considerable force in the jaws, without which C. gujanensis probably could not cut their prey into smaller pieces. However, functional approaches to analysis of forces of the muscle fibers are needed to corroborate / refute the hypotheses mentioned above.
\end{abstract}

Keywords: Rufous-browed Peppershrike, skull, myology.

\section{Musculatura das maxilas de Cyclarhis gujanensis (Aves: Vireonidae)}

\section{Resumo}

O pitiguari (C. gujanensis) é um pássaro neotropical que se alimenta de uma ampla variedade de presas grandes, tais como lagartos, anuros, morcegos e aves. Como são escassos os estudos sobre a anatomia craniana desta espécie, descrevemos a miologia craniana para contribuir com o seu conhecimento anatômico e inferir hipóteses sobre sua anatomia funcional. Foram descritos os músculos adutores mandibulares, externos e internos, do sistema pterigóideo e depressores da mandíbula. O sistema adutor, com a função de elevar a mandíbula, é o mais desenvolvido, particularmente em sua origem na porção caudal da fossa temporal. O músculo depressor da mandíbula possui vários componentes. A maioria dos músculos do aparato mandibular tem tamanho pequeno, porém a ave possui um grande potencial para dilacerar, e essa força provavelmente se deve ao grande número de componentes e pinulações neles presentes. Esses aspectos anatômicos da musculatura indicam uma força considerável nas maxilas, sem a qual C. gujanensis provavelmente não conseguiria cortar suas presas em pedaços menores. No entanto, mais estudos, tanto em abordagens funcionais como análises de forças das fibras musculares, são necessários para corroborar/refutar as hipóteses mencionadas acima.

Palavras-chave: Pitiguari, crânio e miologia.

\section{Introduction}

The Rufous-browed Peppershrike, Cyclarhis gujanensis (Gmelin, 1789), is widely distributed from Mexico to Argentina, living on the edge of the woods, scrubs, parks and wooded gardens (Sick, 1997). It feeds on fruits, worms, insects, caterpillars and lizards (Gekkonidae and Teiidae) (Moojen et al., 1941; Sick, 1997). This little passerine (16 cm in length) uses the beak to tear apart large prey items held down with the foot (Snow, 1964). Recently Ghizoni-Junior et al. (2000) and Andreau and Fernandez (2010) revealed it capturing and tearing big preys as frogs, snakes, bats and birds, a peculiar foraging behavior to a little bird.

Most of studies are focused only on the ecology of C. gujanensis (Sick, 1997; Moojen et al., 1941; Ghizoni-Junior et al., 2000; Andreau and Fernandez, 2010). The morphology system of the feeding apparatus is little known. Only few studies on its anatomy are found (Beecher, 1953; Raikow, 1978; Orenstein and Barlow, 1981), but just the last authors discussed minor functions of the jaws musculature in this bird. Such approaches could help 
us to understand why this little passerine tears apart large prey that could not be swallowed whole at all.

According to Pascotto et al. (2006) the skull shows many morphological variations among families and orders of birds, reflecting expertise in a variety of eating habits in birds. Moreover Donatelli et al. (2014) stand out the importance to study the movements of the beak to apprehension and dilacerations of preys through an analysis from the muscles that move the jaws. In fact, ornithologists should take more importance into the anatomical study of the skull to understand various mechanisms related to the life and evolution of these animals.

Thus, we provided a description of the cranial myology of feeding apparatus on $C$. gujanensis to improve the anatomical knowledge of this species and to generate some hypotheses about functional anatomy.

\section{Material and Methods}

We studied the cranial and jaw myology based on eight adult specimens of $C$. gujanensis. We compared the descriptions with anatomical studies of the cranial myology of Passeriformes from the literature. The material analyzed is from the collections of the Museum of Natural History Taubaté (MHNT: C. gujanensis 630) and the Laboratory of Ecology, Systematics and Conservation of Neotropical Birds - UFMS (LESCAN: C. gujanensis 1, $2,3,11,12,13,14)$.
We focused in muscles associated with the jaws movements. The inconspicuous structures were described using an Olympus SZX12 stereo-microscope (Olympus, Tokyo). The muscles and fascia attached to the jaws have been described and drawn by discarding the skin and fatty tissue, and then we poured the skull into a solution with dye iodine, potassium iodide and distilled water, as proposed by Bock and Shear (1972).

We numbered aponeurosis of origin by arabic numerals and insertions by roman numerals (Höfling and Gasc, 1984). We adopted the nomenclature from the Nomina Anatomica Avium (Baumel et al., 1993) and some nomenclature proposed by Burton (1984).

The comparison of variations on the number of muscle components of the jaw apparatus between Passeriformes (literature) and C. gujanensis is shown in the Table 1.

\section{Results}

The $M$. adductor mandibulae externus rostralis temporalis (Amert) (Figure 1) is bulk and complex. The first component takes origin on the lateral edge of the fossa temporalis with bipinulated aspect (the muscle fibers are converging towards the center). These fibers are rostroventrally oriented for insertion partially on the dorsal and the ventral part of the large aponeurosis I (Figure 1), rostroventrally attached to the aponeurosis V. They are broad and medial to the arcus jugalis. The fibers insert on

Table 1. Variations on the number of muscle components of the jaw apparatus in Passeriformes in comparison with C. gujanensis: Dendrocolaptidae (Donatelli, 1997); Furnariidae (Donatelli and Marceliano, 2007); Drepanididae (Richards and Bock, 1973); Vireonidae (Orenstein and Barlow, 1981). Amert: adductor mandibulae externus rostralis temporalis; Amerl: adductor mandibulae externus rostralis lateralis; Amerm: adductor mandibulae externus rostralis medialis; Amecl: adductor mandibulae externus caudalis lateralis; Amecm: adductor mandibulae externus caudalis medialis; Amev: adductor mandibulae externus ventralis; Psds: pseudotemporalis superficialis; Psdp: pseudotemporalis profundus; DM: depressor mandibulae; Pt V Lat: pterygoideus ventralis lateralis; Pt V Med: pterygoideus ventralis medialis; Pt D Lat: pterygoideus dorsalis lateralis; Pt D Med: pterygoideus dorsalis medialis; Pt Retr: pterygoideus retractor; Prptq: protractor pterygoidei et quadrati.

\begin{tabular}{|c|c|c|c|c|c|}
\hline & Dendrocolaptidae & Furnariidae & Drepanididae & Vireonidae & C. gujanensis \\
\hline Amert & 2 & 3 & 2 & 1 & 3 \\
\hline Amerl & 1 & 2 & 1 & 1 & 1 \\
\hline Amerm & 2 & 3 & 2 & 2 & 2 \\
\hline Amecl & 1 & 1 & 1 (part a) & Not mentioned & 1 \\
\hline Amecm & 1 & 1 & 1 (part b) & 1 & 1 \\
\hline Amev & 1 & 1 & 1 & Not mentioned & 1 \\
\hline Psds & 1 & 1 & 2 & 2 & 2 \\
\hline$P s d p$ & 2 & 2 & 1 & 2 & 1 \\
\hline$D M$ & 3 & 3 & 3 & 4 & 4 \\
\hline Pt V Lat & 1 & 2 & 2 & No component & 1 \\
\hline Pt VMed & 1 & 2 & 3 & $\begin{array}{c}\text { 1, except } \\
\text { Hylophilus spp }\end{array}$ & 2 \\
\hline Pt D Lat & 2 & 1 & 2 & 2 & 2 \\
\hline Pt D Med & 2 & 3 & 2 & 2 & 2 \\
\hline Pt Retr & 2 & 1 & 2 & 1 & 1 \\
\hline Prptq & $\begin{array}{c}\text { 2: M. protractor } \\
\text { quadrati and } \\
\text { pterygoideus }\end{array}$ & 2 & $\begin{array}{c}\text { 2: M. protractor } \\
\text { quadrati and } \\
\text { pterygoideus }\end{array}$ & $\begin{array}{c}\text { 1: anterior and } \\
\text { posterior }\end{array}$ & 1 \\
\hline
\end{tabular}




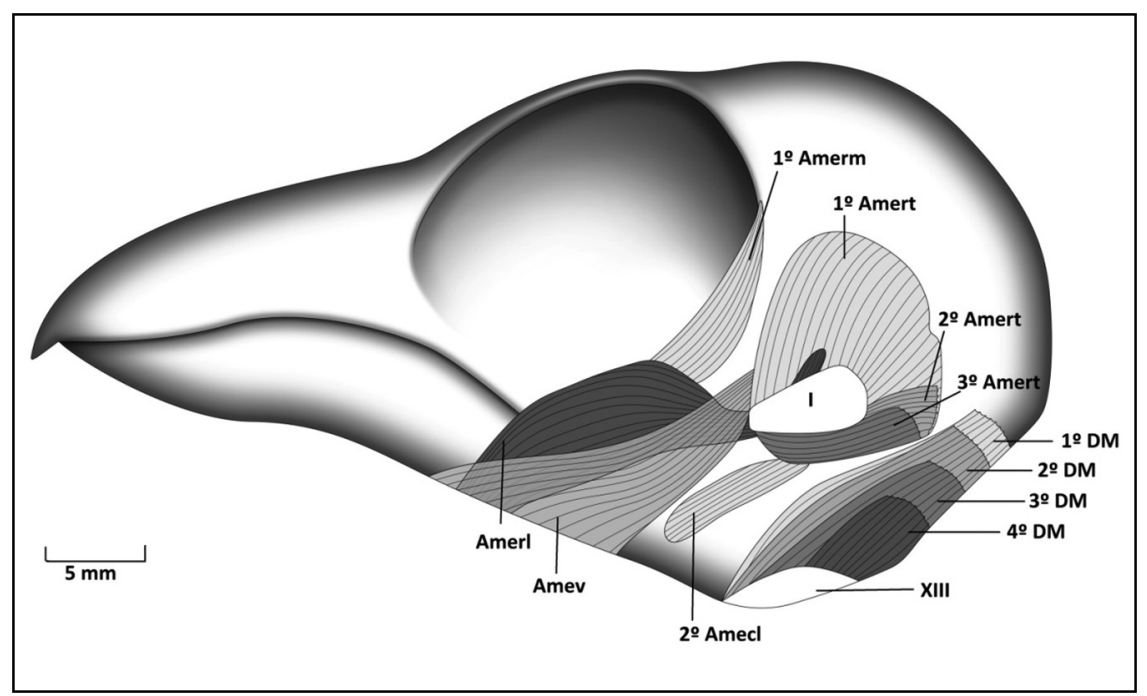

Figure 1. Lateral view of the skull of C. gujanensis. I: aponeurosis of insertion of the first component of M. adductor mandibulae externus rostralis temporalis; XIII: aponeurosis of insertion of the first component of $M$. depressor mandibulae; Amecl: adductor mandibulae externus caudalis lateralis; Amerl: adductor mandibulae externus rostralis lateralis; Amerm: adductor mandibulae externus rostralis medialis; Amert: adductor mandibulae externus rostralis temporalis; Amev: adductor mandibulae externus ventralis; DM: depressor mandibulae; $\mathbf{1}^{\mathbf{0}}, \mathbf{2}^{\mathbf{0}}, \mathbf{3}^{\mathbf{0}}, \mathbf{4}^{\mathbf{0}}$ : first (lateral) to fourth (mesial) components.

the dorsal surface of the mandible, caudally to the proc. coronoideus. The second component takes origin fleshly on the ventrocaudal region of the fossa temporalis, medially to the first component and its fibers run rostrally and insert ventrally on a tenuous aponeurosis II. The aponeurosis II joins to the aponeurosis III for insertion onto the proc. coronoideus. The third and more reduced component gives rise by fleshy fibers of origin in the ventrocaudal region of the fossa temporalis, rostromedially to the previous bundle. Fibers running rostrally insert both on the ventral surface of a tenuous aponeurosis III, which it joins the aponeurosis II, and on the proc. coronoideus. The external portion of Amert is the most robust. The rostroventrally oriented fibers of the broad and robust $M$. adductor mandibulae externus rostralis lateralis (Amerl) (Figure 1) ends in a large aponeurosis I, located medially to the Amert on the dorsocaudal surface of the proc. squamosalis. The first component in the M. adductor mandibulae externus rostralis medialis (Amerm) (Figures 1 and 2) takes origin fleshly and it fibers are ventrally oriented and insert on the ventral portion of a wide aponeurosis $\mathrm{V}$ in the laterodorsal region of the os laterosphenoidale. This aponeurosis joins caudally to the aponeurosis I and inserts on the proc. coronoideus. The second and smaller component is produced by ventrally oriented fleshy fibers ventromedially located to the first component. These fibers are inserted on the ventral surface of a tenuous aponeurosis VI. This aponeurosis inserts onto the medial surface of the mandible, close to the proc. coronoideus. There is one component in the M. adductor mandibulae externus caudalis lateralis (Amecl) (Figure 1) taking origins from a tenuous aponeurosis 2 in the distal part of the proc. oticus os quadratum. Its fibers are lateroventrally oriented for medially insertion onto a tenuous and small aponeurosis
VII, this in turn is part of the dorsal surface of the mandible, caudal to the proc. coronoideus. The fleshy fibers of the M. adductor mandibulae externus caudalis medialis (Amecm) (Figure 2) are rostrally oriented taking origin from the lateroventral portion of the squamosal region. It is medially located to the Amecl and inserted ventrally by a bulky aponeurosis VIII (Figure 1). This aponeurosis VIII inserts on the dorsal surface of the mandible, caudally to the aponeurosis II. The enlarged $M$. adductor mandibulae externus ventralis (Amev) (Figure 1) originates the aponeurosis 3 rostroventrally to the proc. squamosalis. Its fibers are rostroventrally oriented for insertion, laterally onto a broad aponeurosis IX which inserts mostly on the fossa lateralis mandibulae. The Amev is smaller than the Amert, within the adductor mandibular system. Although C. gujanensis has only one component, it is larger than the other muscles. The single $M$. adductor mandibulae posterior (Amp) (Figure 2) takes origin by ventrally oriented fleshy fibers in the laterosphenoid region, close to the os quadratum. It is located medially to the caudal and external adductor mandible muscles. The insertion on the ventral aponeurosis VIII is shared by the aponeurosis of insertion with the Amecm. The Amp is the most reduced muscle of the mandible adductors muscles.

The M. pseudotemporalis superficialis (Psd s) (Figure 2) is multipinulated and trilobed in shape (three oval portions in each component). The first component takes origin as a tenuous aponeurosis 4 on the caudal region of the os laterosphenoidale and its fibers are ventrally oriented, dorsally in the aponeurosis X. This aponeurosis inserts on the tuberculum pseudotemporalis of the mandible. The second component originates as fleshy fibers, medioventrally to the first component. Its fibers are ventrally oriented and insert on the dorsal surface of a tenuous aponeurosis XI 


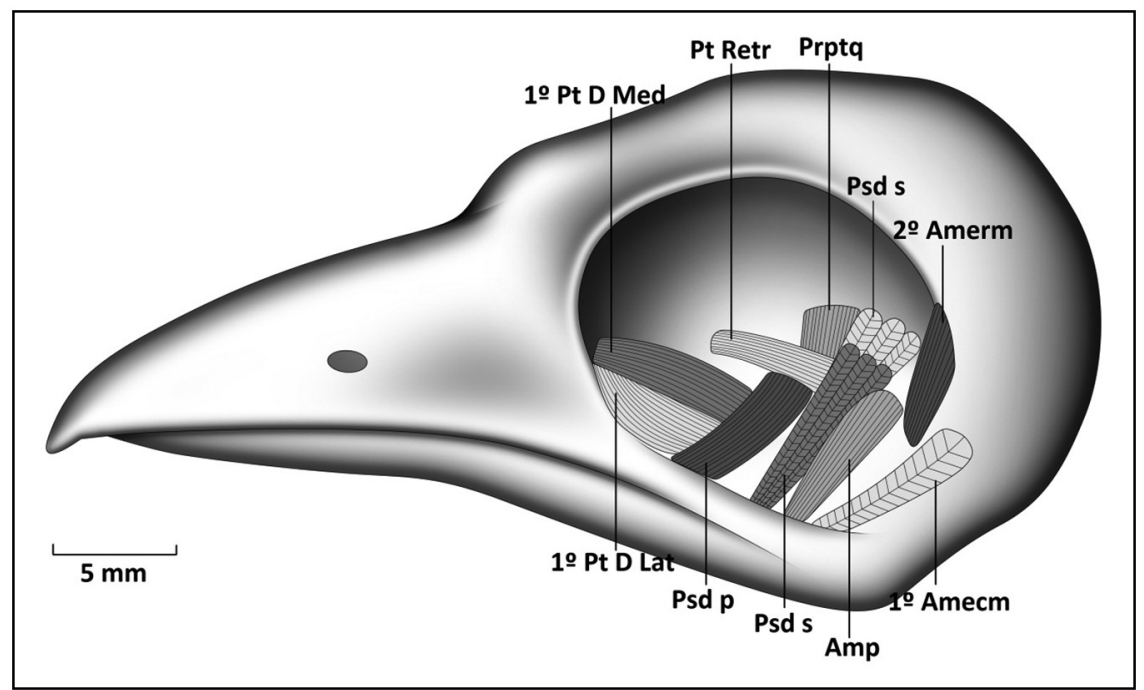

Figure 2. Lateral view of the skull of C. gujanensis. Amecm: adductor mandibulae externus caudalis medialis; Amerm: adductor mandibulae externus rostralis merdialis; Amp: adductor mandibulae posterior; Prptq: protractor pterygoidei et quadrati; Psds: pseudotemporalis superficialis; Psdp: pseudotemporalis profundus; Pt D Lat: pterygoideus dorsalis lateralis; Pt D Med: pterygoideus dorsalis medialis; Pt Retr: pterygoideus retractor; $\mathbf{1}^{\mathbf{0}}, \mathbf{2}^{\mathbf{o}}$ : first (lateral) and second (mesial) component.

that inserts on the medial surface of the mandible, caudally to the aponeurosis X. The enlarged M. pseudotemporalis profundus (Psd p) (Figure 2) originates as the aponeurosis 5 on the proc. orbitalis os quadratum. Its fibers are rostroventrally oriented and inserted on the ventral surface of the aponeurosis XII, which inserts in a broad area on the medial surface of the mandible. The $P s d p$ is larger than $P s d s$, but this muscle also showed only one component.

The first component of the bulky M. depressor mandibulae (DM) (Figure 1) takes origin fleshly in fibers running ventrally on the occipital region. It inserts ventrally onto a thin aponeurosis XIII, which inserts ventrally on the caudal process of the mandible. The second component takes origin from a tenuous aponeurosis 6 in the occipital region, but medioventrally to the first component. Its fibers are ventrally oriented and the insertion on the ventral portion of the aponeurosis XIV. The aponeurosis XIV is divided in two portions: the first inserts on the mandible fossa caudalis and the second on the mandible crista intercotylaris. The third component is a thin aponeurosis 7 in the occipital crest area, ventromedially to the second component. Its fibers are rostroventrally oriented for insertion on the ventral surface of a tenuous aponeurosis $\mathrm{XV}$ inserted on the fossa caudalis of the mandible. The smaller and fourth component shows rostroventrally oriented fibers in a tenuous aponeurosis 8 on the crest on the cavum tympanicum, medioventrally to the third component. Its insertion is by the same aponeurosis on the fossa caudalis mandibulae.

The M. pterygoideus ventralis lateralis (Pt V Lat) (Figure 3) takes origin as a tenuous aponeurosis 9 on the crista lateralis os palatinum with caudally oriented fibers inserted on the ventral surface of a wide aponeurosis XVI.
This aponeurosis takes insertion on the caudoventral portion of the mandible, close to the proc. lateralis mandibulae. The first component of the M. os pterygoideus ventralis medialis (Pt V Med) (Figure 3) takes origin through the thick aponeurosis 10 , in the lateroventral portion of the palate. The fibers are caudally oriented and ventrally inserted onto a tenuous but broad aponeurosis XVII. This aponeurosis inserts ventrally on the proc. medialis mandibulae. The second component takes origin through an aponeurosis 11 on the ventral surface of the os palatinum, dorsally to the fibers of the first component. Its fibers are caudally oriented for insertion through the same aponeurosis on the proc. medialis mandibulae, medially to the first component. The first component of the M. pterygoideus dorsalis lateralis (Pt D Lat) (Figures 2 and 3) takes origin from caudally oriented fleshy fibers on the surface of the dorsocaudal palate. It is inserted dorsally onto a broad aponeurosis XVIII. This aponeurosis inserts in the proc. lateralis mandibulae and on the caudal surface of the mandible either. The second component originates from caudally oriented fleshy fibers on the dorsal surface of the palate, it inserts ventrally in an aponeurosis XIX. This aponeurosis inserts on the base of the proc. medialis mandibulae. There are two components on the bulky M. pterygoideus dorsalis medialis (Pt D Med) (Figures 2 and 3). The origin and insertion is given by four aponeuroses. The first component takes origin from the aponeurosis 12 on the proc. pterygoideum os palatinum. The fibers are caudally oriented and insert dorsally on the aponeurosis XX. This aponeurosis inserts on the proc. medialis mandibulae. The second component originates as the aponeurosis 12 on the dorsal surface of the proc. pterygoideum os palatinum, its fibers are oriented caudally and dorsally it inserts on the aponeurosis XXI. 


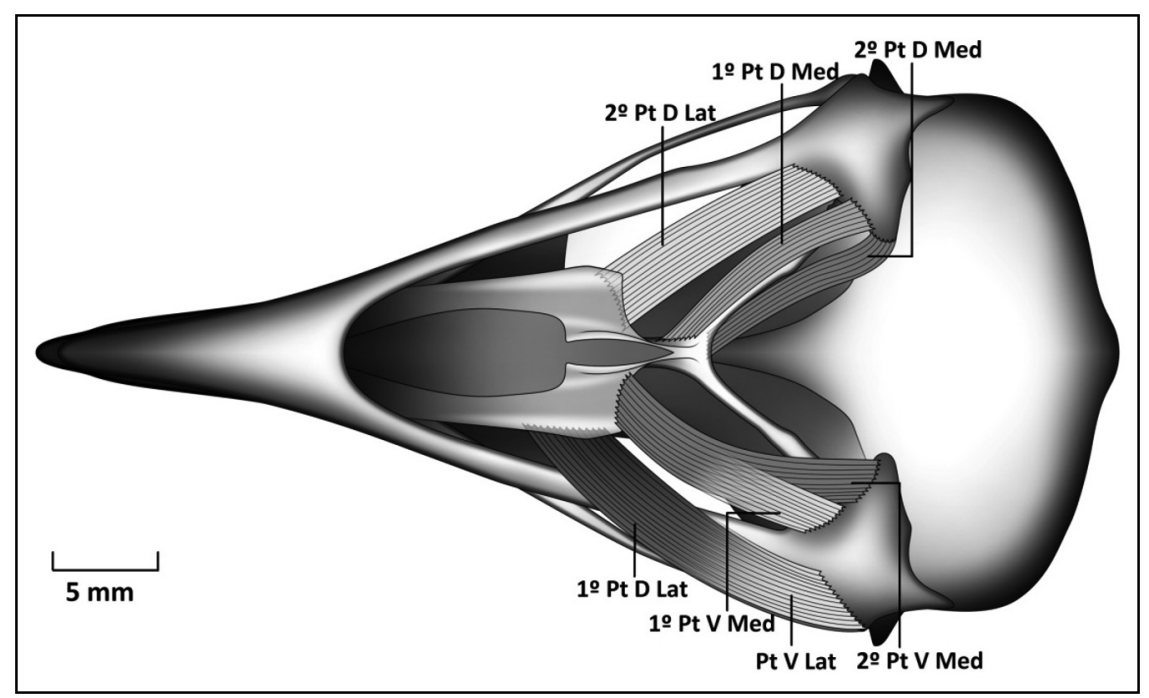

Figure 3. Lateral view of the skull of C. gujanensis. Pt D Lat: pterygoideus dorsalis lateralis; Pt D Med: pterygoideus dorsalis medialis; Pt V Lat: pterygoideus ventralis lateralis; Pt V Med: pterygoideus ventralis medialis; $\mathbf{1}^{\mathbf{0}}, \mathbf{2}^{\mathbf{0}}$ : first (lateral) and second (mesial) components.

This aponeurosis inserts on the caudal portion of the mandible, medially to the aponeurosis XX. The M. pterygoideus retractor (Pt Retr) (Figure 2) originates from caudally oriented fleshy fibers in the rostrodorsal portion of os pterygoideum, close the proc. pterygoideum os palatinum. The insertion is from a tenuous aponeurosis XXII inserts both on the basitemporal region and on the proc. medialis mandibulae. The $M$. protactor pterygoideus et quadrati (Prptq) (Figure 2) takes origin by from ventrally oriented fleshy fibers in the caudoventral region of the orbit, on the dorsal lamina. The insertion is by a tenuous aponeurosis. This aponeurosis takes insertion in two distinct portions: on the proc. mandibularis os quadratum, close to the os pterygoideum and on the medial part of the base of the proc. orbitalis os quadratum. This muscle is housed medially to the $P s d s$.

\section{Discussion}

The robustness of the external portion of the Amert is expected from a bird with strong adduction to tear larger prey onto small pieces, as C. gujanensis. Furthermore, Orenstein and Barlow (1981) observed that the origin of this muscle from fleshy fibers is in the region of the fossa temporalis, but in some vireos, including C. gujanensis, they found a component of this muscle with the aponeurotic origin in the crista subtemporalis. Nevertheless, we did not observed any component of this muscle taking origin from aponeurosis in C. gujanensis, only from fleshy fibers on the fossa temporalis. In Loxops (Family: Drepanididae) Richards and Bock (1973) found that this muscle has origin and insertion from fleshy fibers and aponeurosis, respectively. Richards and Bock (1973) argued that the form and size of the proc. squamosalis is not related to the size of the Amerl. However, in C. gujanensis is possible to observe a positive correlation between the large and long proc. squamosalis to the robustness of the Amerl. In addition, in $V$. chivi and V. olivaceus the proc. squamosalis is reduced and also this muscle is not large in many species of Vireo (Orenstein and Barlow, 1981). The origin and insertion features of Amev do not appear to vary in some Passeriformes (Donatelli, 1997; Donatelli and Marceliano, 2007). In Loxops coccinea (Richards and Bock, 1973) is originated both from fleshy fibers and aponeurosis and it is the most reduced muscle of the external adductor system in Drepanididae. In other birds (Burton, 1984) this muscle origins and inserts in similar regions. As this muscle is directly connected to the adductor mandibular and it is large in $C$. gujanensis, this could indicate a strong capacity for prehensile beak. When present in Passeriformes, the Amp also usually appears to be underdeveloped (Orenstein and Barlow, 1981; Donatelli, 1997; Donatelli and Marceliano, 2007). This is due to the larger Psd $p$ which restricts the Amp to a narrower portion on the proc. otical of the corpus quadrati (Donatelli and Marceliano, 2007).

Orenstein and Barlow (1981) observed the origin from a small aponeurosis in vireos, including the trilobed and multipinulated aspect of Psd $s$. This muscle is subject to much variation concerning the size of lobes and degree of pinnulation among vireos species and the bipinulated condition is well developed in the internal component in C. gujanensis. In some passerines (Donatelli, 1997; Donatelli and Marceliano, 2007) it originates from fleshy fibers. Richards and Bock (1973) found the origin from fleshy fibers and aponeurosis. The place of origin and insertion of this muscle in different passerines above does not vary from the results presented here. The robustness and high number of fibers for the Psd s can ensure stability as these characteristics are related to the muscle force (Gans and Bock, 1965). However, in C. gujanensis this muscle is reduced. Orenstein and Barlow (1981) stated that 
a large $P s d s$ is practically impossible in vireos, because of its position within the orbit which limits space in the presence of the eye and associated structures. On the other hand, the $P s d s$ has short fibers with high pinnulation in order to counterbalance this problem. Thus, the size of the fibers does not interfere with muscle contractions; in addition, smaller fibers are energetically more economical. It is important to stand out that, for a specific volume and length of some muscle, more extent of pinnulation increases the cross-sectional area of the fibers and consequently the production of forces (Hildebrand and Goslow, 2006). This probably explains the existence of pinnulation on small muscles in C. gujanensis.

Although the depressor muscle system of the mandible causes its opening (Bulher, 1981), it is also effective in elevating the upper jaw, mainly due to the postorbital ligament (Bock, 1964; Zusi, 1962). Despite of the reduced proc. retroarticularis, the DM is large in C. gujanensis, it would make this muscle more powerful (Bulher, 1981). This muscle is complex (four components and seven aponeuroses), and it originates from fleshy fibers only in the most external component. In vireos most of the fibers from this large muscle originate as a short aponeurosis, but it is inserted from both fibers fleshy and aponeurosis (Orenstein and Barlow (1981). In passerines (Donatelli, 1997; Donatelli and Marceliano, 2007) the number of aponeuroses is reduced. This muscle is conservative for most groups of birds (Burton 1984), but in this study and in passerines (Richards and Bock, 1973; Donatelli, 1997; Donatelli and Marceliano, 2007) the $D M$ presents high heterogeneity in relation to size, component number (as shown in Table 1) and patterns of origin and insertion.

The pterygoideum system is composed by five muscles and it is responsible for the depression of the upper jaw due to pulling the both os palatine/os pterygoideum back and the elevation of the mandible by the contraction of these muscles (Bulher, 1981). The Pt V Lat is wide with a single component in C. gujanensis. Orenstein and Barlow (1981) found no muscle component in all Vireonidae species. There is high variety to the patterns of origin and insertion for this muscle at the literature (Richards and Bock, 1973; Burton, 1984; Donatelli, 1997; Donatelli and Marceliano, 2007). In C. gujanensis we observed both origin and insertion only by aponeurosis. The insertion of the $\mathrm{Pr}$ D Lat is similar to Vireonidae (Orenstein and Barlow, 1981). In Passeriformes (Richards and Bock, 1973; Donatelli, 1997; Donatelli and Marceliano, 2007) the insertion is in the proc. medialis of the mandible. The pattern of origin by fleshy fibers and insertion by aponeurosis for this muscle appears to be conservative in passerines (Richards and Bock, 1973; Donatelli, 1997; Donatelli and Marceliano, 2007). According to Orenstein and Barlow (1981), the robustness to the Pt D Lat and also to the external adductor muscles provided quite potent jaws in the $C$. gujanensis and Vireolanius leucotis. The same was not observed for the other vireos. In woodcreepers the fleshy fibers take origin from both components (Donatelli, 1997) in the Pt D Med, while in Philydorinae (Donatelli and Marceliano, 2007) there is notable three and four components aponeurosis of insertion, but the origin is from fleshy fibers. In all Vireonidae, Orenstein and Barlow (1981) described this muscle divided onto two parts: the anterior and posterior. The anterior is originated in the lateral surface of the os pterygoideum and the posterior by the some aponeurosis origin for the $\operatorname{Pr} V \mathrm{Med}$. These authors also state that the anterior portion of this muscle in C. gujanensis is large and it originates from both the os palatinum and os pterygoideum. Possibly this occurred due to sharing aponeurosis of origin, which led Orenstein and Barlow (1981) to designate this muscle in a different manner. The Prptq has only one poorly developed component. It rotates the os quadratum so that it rostrally pushes the palatine/archus jugalis, providing upper jaw elevation (Bulher, 1981).

We found sixteen muscles related to the mandibular adductor system in C. gujanensis. When compared with other birds, the muscles are robust with high complexity regarding to the components in each muscle either, except for the pterigoideus muscles. Moreover we noticed different patterns of muscular origin and insertion, the latter being directly attached in the bone or as aponeurosis. The multipinnate Amert is the greatest muscle. According to Orenstein and Barlow (1981) it increases the strength due to increased cross-sectional area. Although the $P s d s$ is reduced its remarkable pinnulation also probably increases the strength. The DM and many muscles of pterygoideum system are robust and large with many components compared with other birds. Such complexity seems to result on high ability to capture, rip and tear larger prey, since the more complex and robust are these muscles, the more ability to manipulate preys (Richards and Bock, 1973).

In summary, we hypothesized the strength of jaw apparatus in C. gujanensis is related to the large bones and muscles or pinnulation in reduced muscles. These strong and complex pinnulated adductor system probably increases the strength in the jaw adduction in C. gujanensis. This muscle complexity, together with some bones adaptations, seems to enable $C$. gujanensis to take and tearing preys considered large for a Vireonidae species. These anatomical descriptions could partially explain its peculiar feeding behavior in comparison with other Vireonidae. However, further studies on functional approaches and analyzes of muscle fibers forces are necessary to corroborate/refute the hypotheses mentioned above.

\section{Acknowledgements}

We are grateful to Herculano Alvarenga (MHNT) to permit the descriptions in loco. We also thank to André V. C. Levorato by the illustrations and Maria F. M. Ortiz by the English version of the manuscript.

\section{References}

ANDREAU, M. and FERNANDEZ, DP., 2010. Predación del juan chiviro (Cyclarhis gujanensis) sobre aves, murciélagos, reptiles y anfíbios. Nuestras Aves, vol. 54, p. 43-45. 
BAUMEL, JJ., KING, AS., BREAZILE, JE., EVANS, HE. and BERGE, JCV., 1993. Handbook of avian anatomy: Nomina Anatomica Avium. 2nd ed. Cambridge: Nuttal Ornithological Club. 779 p.

BEECHER, WJ., 1953. A phylogeny of the oscines. The Auk, vol. 70, p. 270-333.

BOCK, WJ. and SHEAR, CHR., 1972. A staining method for gross dissection of vertebrate muscles. Anatomischer Anzeiger, vol. 130, p. 222-227.

BOCK, WJ., 1964. Kinetics of the avian skull. Journal of Morphology, vol. 114, p. 1-42.

BULHER, PL. 1981. Functional anatomy of the avian jaw apparatus. In KING, ASE. and MELELLANEDS, J. (Eds.). Form and function in birds. London: Academic Press. p. 439-469. vol. 2.

BURTON, PJK., 1984. Anatomy and evolution of the feeding apparatus in the avian orders Coraciformes and Piciformes. Bulletin of the British Museum Natural History, vol. 47, no. 6, p. 331-443.

DONATELLI, RJ. and MARCELIANO, MLV., 2007. Osteologia e miologia cranianas de Megaxenops parnaguae (Furnariidae: Philydorinae). Boletin Museu Paraense Emílio Goeldi Ciências Naturais, vol. 2, no. 1, p. 183-215.

DONATELLI, RJ., 1997. Osteologia e miologia cranianas de Dendrocolaptidae (Passeriformes, Tyranni) 1. Gêneros Glyphorynchus, Campylorhamphus, Dendrocincla, Xiphorhynchus e Dendrocolaptes. Ararajuba, vol. 5, no. 1, p. 19-37.

DONATELLI, RJ., HÖFLING, E. and CATALANO, AL., 2014. Relationship between jaw apparatus, feeding habit and food source in the Oriental woodpeckers. Zoological Science, vol. 31 , no. 4, p. 223-227.

GANS, C. and BOCK, WJ., 1965. The functional significance of muscle architecture: a theoretical analysis. Ergebnisse der Anatomie, vol. 38, p. 115-142.
GHIZONI-JUNIOR, IR., AZEVEDO, MAG. and PORTCARVALHO, M., 2000. Predação de Hyla nahdereri (Anura: Hylidae) por Cyclarhis gujanensis (Aves: Vireonidae) em Santa Catarina. Melopsittacus, vol. 3, no. 3, p. 137-139.

HILDEBRAND, M. and GOSLOW, G., 2006. Análise da estrutura dos vertebrados. São Paulo: Atheneu Editora. 637 p.

HOFLING, E. and GASC, JP., 1984. Biomécanique du crane et du bec chez Ramphastos (Aves: Ramphastidae). Gegenbaurs Morphologisches Jahrbuch, vol. 1, p. 125-147.

MOOJEN, J., CARVALHO, JCM. and LOPES, HS., 1941. Observações sobre o conteúdo gástrico das aves brasileiras. Memorias do Instituto Oswaldo Cruz, vol. 36, p. 405-444.

ORENSTEIN, RI. and BARLOW, JC., 1981. Variation in the jaw musculature of the avian family Vireonidae. Toronto: Royal Ontario Museum. 60 p. Life Sciences Contribution, no. 128.

PASCOTTO, MC., HOFLING, E. and DONATELLI, RJ., 2006. Osteologia craniana de Coraciformes (Aves). Revista Brasileira de Zoologia, vol. 23, no. 3, p. 841-864.

RAIKOW, RJ., 1978. Appendicular myology and relationships of the New World nine-primaried oscines (Aves: Passeriformes). Bulletin of Carnegie Museum of Natural History, vol. 7, p. 1-43.

RICHARDS, LP. and BOCK, WJ., 1973. Functional anatomy and adaptative evolution of the feeding apparatus in the Sawaiian honeycreeper genus Loxops (Drepanidae). Ornithological Monographs, vol. 15, p. 1-73.

SICK, H., 1997. Ornitologia brasileira. Rio de Janeiro: Nova Fronteira. 862 p.

SNOW, DW., 1964. Peper-shisker. In THOMPSON, AL. (Ed.). A new dictionary of birds. London: Nelson. 928 p.

ZUSI, RL., 1962. Structural adaptations of the head and neck of the Black skimmer Rhynchops niger Linnaeus. Cambridge: Nuttal Ornitholgical Club. 101 p. 